\title{
Contract Officer
}

National Cancer Institute

\section{Source}

National Cancer Institute. Contract Officer. NCI Thesaurus. Code C51816.

A person with the authority to enter into, administer, and/or terminate contracts and

make related determinations and findings. 